\title{
Preparation, Characterization of A New Cis - lodoplatin and Cis - Carboplatin Complexes and Study There Spectral, Physical and Pharmaceutical Properties
}

\author{
Jasim M. Abdul Hussein Saadon A. Owda Samaá M. Hassan \\ Chemistry Department, College of Science, University of Babylon, Hilla, Iraq \\ mjaseem67@yahoo.com
}

ARTICLE INFO

Submission date: $17 / 9 / 2018$

Acceptance date: $13 / 11 / 2018$

Publication date: 10/3/2019

\begin{abstract}
This search includes preparation of new cis-platin, in the form of iodin, and new two cis carboplatin complexes $\left\{\mathrm{cis} \quad\left[\mathrm{Pt}\left(4-\right.\right.\right.$ aminoantipyrine) $\left.\left(\mathrm{NH}_{3}\right)_{2}\right] \mathrm{I}_{2}$ and cis[Pt (aminosalicylicacid) $\left.\left.\left(\mathrm{NH}_{3}\right)_{2}\right] \mathrm{I}\right\}$, which used as anti - cancer drugs, they are prepared by using the organic ligands 4-amino salicylic acid and 4-amino anti pyrine. These complexes were characterized by using UV-Vis., FTIR, XRD and ${ }^{1}$ HNMR spectroscopic techniques. The effect of the concentration and the temperature on the molar electrical conductivity of its solutions were studied. The expiry date (half-life) for the solutions of the complexes in the circumstances at the degrees $\left(35^{\circ} \mathrm{C}\right)$ and $\left(20^{\circ} \mathrm{C}\right)$ was determined.
\end{abstract}

Keyword: Cis-[Diaminodiiodoplatinum(II)], Carboplatin, XRD, ${ }^{1} \mathrm{HNMR}$.

Abbreviations:

4 - aminoantipyrine: 4-AAP

4 - aminosalcylicacid: 4-ASA

\section{Introduction}

Cis - platin and cis - carboplatin complexes are coordination complexes of platin (II) and classify as anti - cancer drugs according to American drugs record[1]. The DNA nuclear acid in the cell is the target of the cis - platin [2],[3]. Cis carboplatin is less toxic than cis - platin and more active against the same tumor[4]. Carboplatin had been using for long time for the treatment of many types of tumors such as lung tumors and contrast of cis-platin mechanism, carboplatin linked

(C) Journal of University of Babylon for Pure and Applied Sciences (JUBES) by University of Babylon is licensed under a Creative Commons Attribution 4.0 International License 
covalently with the DNA nuclear acid and do not cause any kidney poisoning or nausea or puke and its poisoning is inhibition bone marrow, which leads to decrease the platelets, therefore, it is more used than cis - platin for the patients who suffer from toxic intolerances of cis - platin, also cis - carboplatin has more stability in blood plasma than cis - platin [5]. The proposed mechanism for cis - platin to stop the cell division is: cis - platin can enter inside the cell easily and associated with the two sandwiches of the DNA at the same by hydrogen bonds during nitrogen, sulfur and oxygen atoms cause to kill the cancer cell[6].

\section{Excremental}

\section{1-Prepration of cis - iodoplatin: $\left[\mathrm{Pt}\left(\mathrm{NH}_{3}\right)_{2} \mathbf{I}_{2}\right][7-10]$ :}

In a small beaker $(0.003 \mathrm{~mol}, 1.25 \mathrm{~g})$ of $\left(\mathrm{K}_{2} \mathrm{PtCl}_{4}\right)$ was put and $(2 \mathrm{ml})$ of distilled water was added. The solution was heated in a water bath at $\left(40{ }^{\circ} \mathrm{C}\right)$ and $\mathrm{KI}$ solution $((0.015 \mathrm{~mol})(2.5 \mathrm{~g})$ in $5 \mathrm{ml}$ hot distilled water was added. The color of the resulting solution changed from red-brown to red- black. This solution was heated to $\left(70{ }^{\circ} \mathrm{C}\right)$ with stirring after that add drop wise $(5 \mathrm{ml})$ of ammonia solution $(2 \mathrm{M})$ to control the $\mathrm{Ph}$ at 7 , soon a fine yellow crystals of cis- $\left[\mathrm{Pt}\left(\mathrm{NH}_{3}\right)_{2} \mathrm{I}_{2}\right)$ precipitate was formed. To adjust the $\mathrm{PH}$, add ammonium chloride $(0.2 \mathrm{~g})$ as a buffer solution to prevent the formation of hydroxide complex. Heat the solution to a $\left(60{ }^{\circ} \mathrm{C}\right)$ for one hour and take care of that the $\mathrm{pH}$ not raised above 7 . Cool the solution by using ice bath, soon greenish - brown precipitate was formed. Filter and wash with $10 \mathrm{ml}$ of cool ethanol and with $30 \mathrm{ml}$ of cool distilled water, product percentage was (85\%) according to the following equations

$$
\begin{aligned}
& \mathrm{K}_{2} \mathrm{PtCl}_{4}+4 \mathrm{KI} \rightarrow \mathrm{K}_{2} \mathrm{PtI}_{4}+3 \mathrm{KCl} \\
& \mathrm{K}_{2} \mathrm{PtI}_{4}+2 \mathrm{NH}_{4} \mathrm{OH} \rightarrow \mathrm{cis}-\left[\mathrm{Pt}\left(\mathrm{NH}_{3}\right)_{2} \mathrm{I}_{2}\right]+2 \mathrm{KI}+2 \mathrm{H}_{2} \mathrm{O}
\end{aligned}
$$

\section{2-Preparation of cis - $\left[\mathrm{Pt}(4-a m i n o a n t i p y r i n e)\left(\mathrm{NH}_{3}\right)_{2}\right] \mathbf{I}_{2}$ :}

In distilled flask $(0.00083 \mathrm{~mol}, 0.4 \mathrm{~g})$ of cis- $\left[\begin{array}{llll}\mathrm{Pt} & \left(\mathrm{NH}_{3}\right) & { }_{2} \mathrm{I}_{2}\end{array}\right]$ and $(0.00083 \mathrm{~mol}, 0.17 \mathrm{~g})$ of (4-amino anti pyrine) reagent were mixed and dissolved in $(20 \mathrm{ml})$ of absolute ethanol. By reflux process, at $\left(80{ }^{\circ} \mathrm{C}\right)$ with stirring for three hours, the reaction was done. Brown precipitate was formed. The mixture was cooled in ice bath. Filtrated and washed with $(10 \mathrm{ml})$ of ethanol and $(20 \mathrm{ml})$ of cooled water. The following equation to make clear this reaction:

$$
\begin{aligned}
& \text { cis }-\left[\operatorname{Pt}\left(\mathrm{NH}_{3}\right)_{2} \mathrm{I}_{2}\right]+4-\text { a min oantipyrine } \rightarrow \\
& \text { cis- }-\left[\operatorname{Pt}(4-a \min \text { oantipyrine })\left(\mathrm{NH}_{3}\right)_{2}\right] I_{2}
\end{aligned}
$$

\section{3-Prepration of cis - $\left[\mathrm{Pt}(4-a m i n o s a l i c y l i c a c i d)\left(\mathrm{NH}_{3}\right)_{2}\right] \mathrm{I}$ :}

In distilled flask $(0.00083 \mathrm{~mol})(0.4 \mathrm{~g})$ of cis- $\left[\mathrm{Pt}\left(\mathrm{NH}_{3}\right)_{2} \mathrm{I}_{2}\right]$ and $(0.00083 \mathrm{~mol})($ $0.122 \mathrm{~g}$ ) of (4-amino salicylic acid) reagent were mixed and dissolved in $(20 \mathrm{ml})$ of 
absolute ethanol. The $\mathrm{pH}$ of the solution was adjust between (8-7) so the solution become light basic by using very dilute potassium hydroxide solution. By reflux process, at $\left(80^{\circ} \mathrm{C}\right)$ with stirring for three hours, the reaction was done.. The mixture was cooled in ice bath. Filtrated and washed with (10ml) of ethanol and (20 ml) of cool water Black precipitate was formed. The following equation to make clear this reaction:

$$
\begin{aligned}
& \text { cis }-\left[\mathrm{Pt}\left(\mathrm{NH}_{3}\right)_{2} \mathrm{I}_{2}\right]+4-\text { a min osalicylicacid } \rightarrow \\
& \text { cis }-\left[\operatorname{Pt}(4-\text { a min osalicylicacid })\left(\mathrm{NH}_{3}\right)_{2}\right] I
\end{aligned}
$$

\section{4 - Physical, spectral and pharmaceutical studies:}

The prepared complex was characterized by UV. Vis., FTIR and HNMR spectra. XRD spectra for the cis - iodoplatinum complex was recorded by using X-ray diffraction technique. HNMR spectra for the complexes were measured. Molar conductivity was measured, for the prepared complexes with different concentrations, from $8 \times 10^{-3} \mathrm{M}$ to $1 \times 10^{-4} \mathrm{M}$ at $35^{0} \mathrm{C}$. The change in molar connectivity at different temperatures from $80{ }^{\circ} \mathrm{C}$ to $20{ }^{\circ} \mathrm{C}$ was measured. The effect of temperature of the prepared complexes $\left(4 \times 10^{-4} \mathrm{M}\right)$ studied by using UV. Vis. technique at different temperatures $\left(80-20{ }^{0} \mathrm{C}\right)$. The expiry date of the complex solutions $\left(1 \times 10^{-3} \mathrm{M}\right)$ at two temperatures, $40{ }^{\circ} \mathrm{C}$ and $20^{\circ} \mathrm{C}$, was studied by using UV. Vis. Technique, in which the absorbance was measured at each (48) hour for 20 days.

\section{Results and Discussion}

\section{1-UV.Vis. spectra:}

The electronic spectra of the complexes cis-[Pt(4-aminoantipyrine) $\left.\left(\mathrm{NH}_{3}\right)_{2}\right] \mathrm{I}_{2}$ and cis-[Pt(4-aminosalicylicacid) $\left.\left(\mathrm{NH}_{3}\right)_{2}\right] \mathrm{I}$, show that $\lambda_{\max }$ are $(495 \mathrm{~nm})(440 \mathrm{~nm})$ respectively which belong to the transmission $\left(M \rightarrow\right.$ L.C.T.) [11]. The $\lambda_{\max }(364 \mathrm{~nm})$ $(330 \mathrm{~nm})$ which belong to the transmission $(\mathrm{n} \rightarrow \pi *)[12]$ and the $\lambda_{\max }(296 \mathrm{~nm})(304$ $\mathrm{nm})$ which belong to the transmission $\left(\pi-\rightarrow \pi^{*}\right)$ [13], while the complex cis$\left.\left[\mathrm{Pt}\left(\mathrm{NH}_{3}\right)_{2} \mathrm{I}_{2}\right)\right]$ shows a $\lambda_{\max }(302 \mathrm{~nm})$ which belongs to the transmission $(\mathrm{M} \rightarrow$ L.C.T. $)$. table (1)and figures $(1,2,3)$ show these results. The differences in $\lambda_{\max }$ between the primary material and the complexes is a good evidence for the formation the new complexes. 
Journal of University of Babylon, Pure and Applied Sciences, Vol.(27), No.(1): 2019

Table (1): UV.Visb. data for the prepared complexes

\begin{tabular}{|l|c|l|l|}
\hline \multicolumn{1}{|c|}{ Compounds } & \multicolumn{1}{|c|}{$\boldsymbol{\lambda ( \mathbf { n m } )}$} & \multicolumn{1}{|c|}{$\mathbf{V}(\mathbf{c m}$} & \multicolumn{1}{|c|}{$\begin{array}{c}\text { 1ype of } \\
\text { transition }\end{array}$} \\
\hline Cis-[Pt($\left.\left.\left(\mathrm{NH}_{3}\right)_{2} \mathrm{I}_{2}\right)\right]$ & 302 & 33112 & $\mathrm{M} \rightarrow$ L.C.T. \\
\hline Cis-[Pt(4-AAP) $\left.\left(\mathrm{NH}_{3}\right)_{2}\right] \mathrm{I}_{2}$ & 296 & 33783 & $\pi^{*} \rightarrow \pi$ \\
& 364 & 27472 & $\mathrm{n} \rightarrow \pi^{*}$ \\
& 495 & 20202 & $\mathrm{M} \rightarrow$ L.C.T. \\
\hline Cis-[Pt(4-ASA) $\left.\left(\mathrm{NH}_{3}\right)_{2}\right] \mathrm{I}$ & 304 & 23894 & $\pi^{*} \rightarrow \pi$ \\
& 330 & 30303 & $\mathrm{n} \rightarrow \pi^{*}$ \\
& 440 & 22727 & $\mathrm{M} \rightarrow$ L.C.T. \\
\hline
\end{tabular}

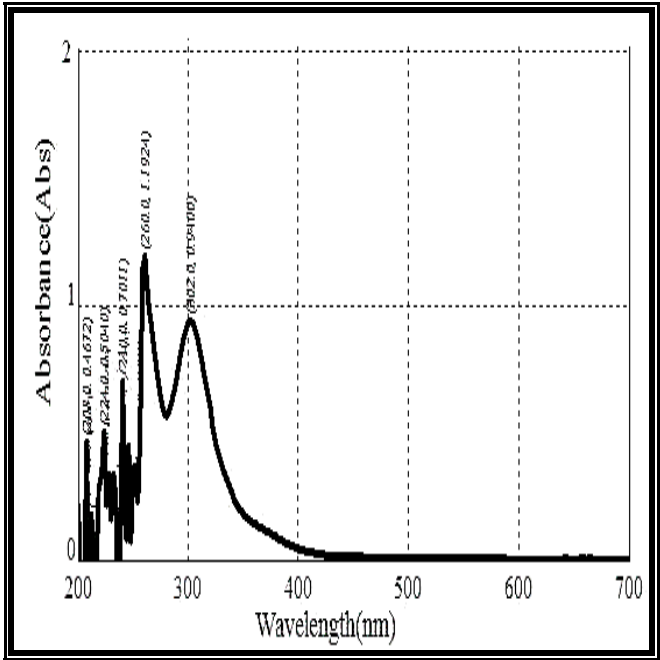

Figure (1): UV-Vis. spectrum for cis-[ $\left.\left.\operatorname{Pt}\left(\mathrm{NH}_{3}\right)_{2} \mathrm{I}_{2}\right)\right]$ 


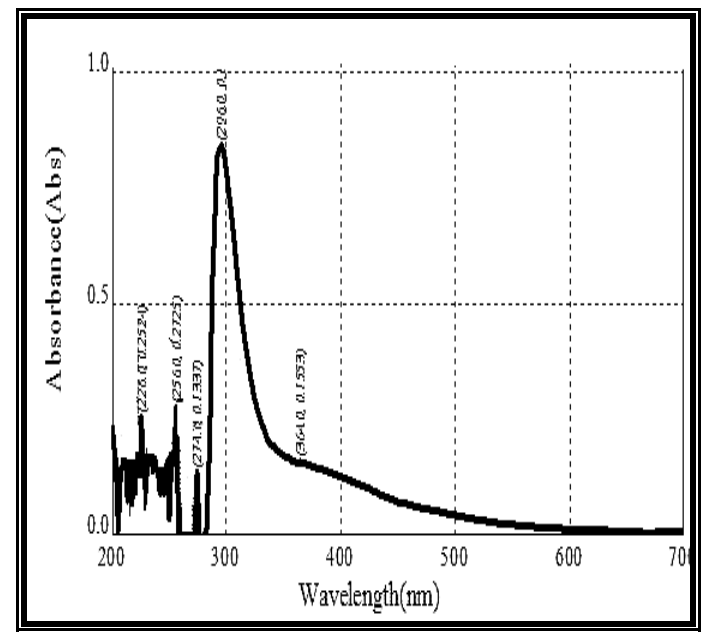

Figure (2): UV-Vis. spectrum for cis-[Pt(4-AAP) $\left.\left(\mathrm{NH}_{3}\right)_{2}\right] \mathrm{I}_{2}$

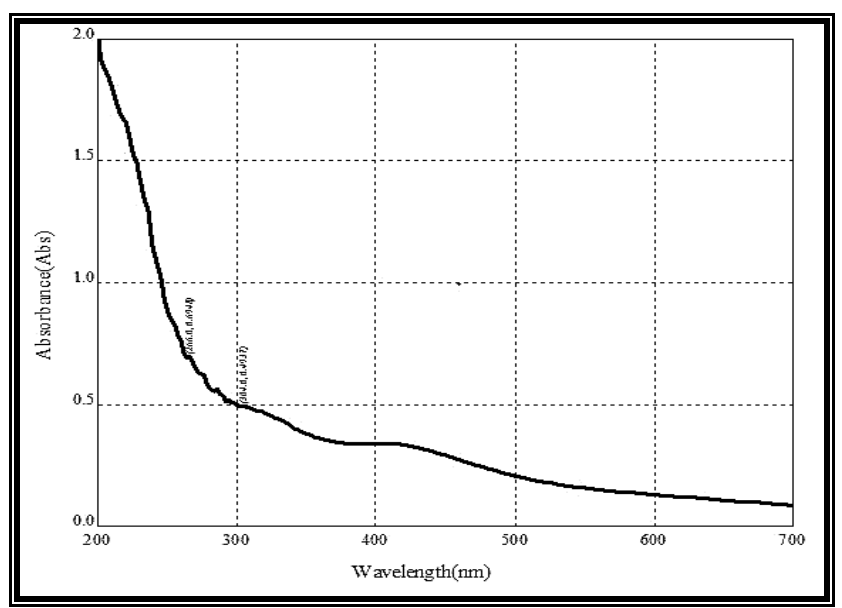

Figure (3): UV-Vis. spectrum for cis-[Pt(4-ASA) $\left.\left(\mathrm{NH}_{3}\right)_{2}\right] \mathrm{I}$

\section{FTIR spectra:}

The FTIR spectra for the complexes cis- $\left.\left[\mathrm{Pt}\left(\mathrm{NH}_{3}\right)_{2} \mathrm{I}_{2}\right)\right]$, cis-[Pt(4-AAP)(NH 3$\left.)_{2}\right] \mathrm{I}_{2}$ and cis-[Pt(4-ASA) $\left.\left(\mathrm{NH}_{3}\right)_{2}\right] \mathrm{I}$ show the frequencies $\left(595 \mathrm{~cm}^{-1}\right),\left(586 \mathrm{~cm}^{-1}\right)$ and $\left(546 \mathrm{~cm}^{-1}\right)$ belong to the bond (M-N) respectively. The the frequencies $\left(498 \mathrm{~cm}^{-1}\right)$ and $\left(441 \mathrm{~cm}^{-1}\right)$ for the complexes Cis-[Pt(4-AAP) $\left.\left(\mathrm{NH}_{3}\right)_{2}\right] \mathrm{I}_{2}$ and cis-[Pt(4-ASA) $\left(\mathrm{NH}_{3}\right)_{2}$ ]I respectively belong to the transmission $(\mathrm{M}-\mathrm{O})$ respectively, and the frequency $\left(3251 \mathrm{~cm}^{-1}\right)$ belongs to the bond $(\mathrm{O}-\mathrm{H})$ of the complex cis-[Pt(4-ASA) $\left.\left(\mathrm{NH}_{3}\right)_{2}\right] \mathrm{I}$ [14], table (2) and figures $(4,5,6)$ show these results. The shifting, 
removing and appearing of some frequencies is an evidence of the formation of new complexes.

Table (2): Explain the frequencies FTIR spectra for the complexes

\begin{tabular}{|c|c|c|c|c|c|c|}
\hline Compounds & $(\mathbf{N}-\mathrm{H})$ & $\begin{array}{l}(\mathrm{N}-\mathrm{N}), \\
(\mathrm{N}=\mathrm{N})\end{array}$ & $\begin{array}{l}(\mathrm{C}= \\
\text { O) }\end{array}$ & $\begin{array}{l}\text { (M- } \\
\text { N) }\end{array}$ & $\begin{array}{l}\text { (M- } \\
\text { O) }\end{array}$ & $\begin{array}{l}\text { (O- } \\
\mathrm{H})\end{array}$ \\
\hline Cis- $\left.\left[\mathrm{Pt}\left(\mathrm{NH}_{3}\right)_{2} \mathrm{I}_{2}\right)\right]$ & $\begin{array}{l}3272 \mathrm{~s} \\
1290 \mathrm{w}\end{array}$ & & & $\begin{array}{l}595 \\
\mathrm{~m}\end{array}$ & & \\
\hline $\begin{array}{c}\text { Cis- }[\mathrm{Pt}(4- \\
\left.\text { AAP })\left(\mathrm{NH}_{3}\right)_{2}\right] \mathrm{I}_{2}\end{array}$ & $\begin{array}{l}3431 \mathrm{~s} \\
1161 \mathrm{w}\end{array}$ & $1492 \mathrm{~s}$ & $\begin{array}{l}164 \\
3 s\end{array}$ & $\begin{array}{l}586 \\
\mathrm{~m}\end{array}$ & $\begin{array}{l}498 \\
\mathrm{~m}\end{array}$ & \\
\hline $\begin{array}{r}\text { Cis-[Pt(4- } \\
\left.\text { ASA) }\left(\mathrm{NH}_{3}\right)_{2}\right] \mathrm{I}\end{array}$ & $\begin{array}{l}3461 s \\
1028 w\end{array}$ & & $\begin{array}{l}160 \\
8 s\end{array}$ & $\begin{array}{l}547 \\
\mathrm{~m}\end{array}$ & $\begin{array}{l}441 \\
\mathrm{~m}\end{array}$ & $\begin{array}{l}325 \\
1 b\end{array}$ \\
\hline
\end{tabular}

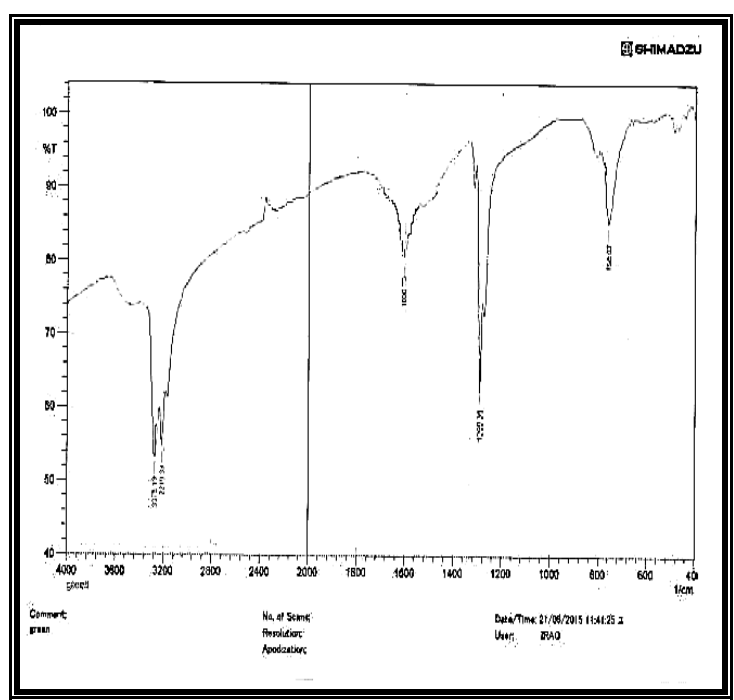

Figure (4): FTIR spectrum for Cis-[Pt( $\left.\mathrm{NH}_{3}\right)_{2} \mathrm{I}_{2}$ 


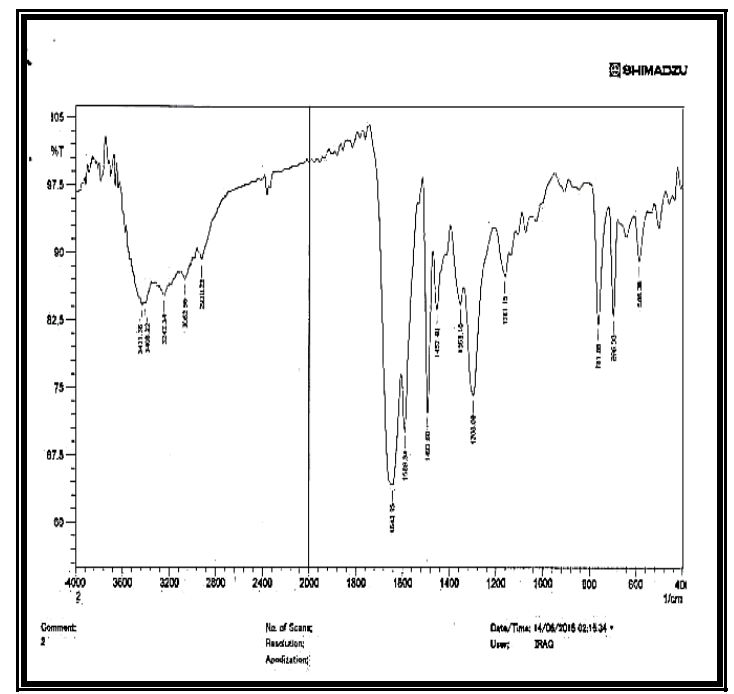

Figure (5): FTIR spectrum for Cis-[Pt(4-AAP) $\left.\left(\mathrm{NH}_{3}\right)_{2}\right] \mathbf{I}_{2}$

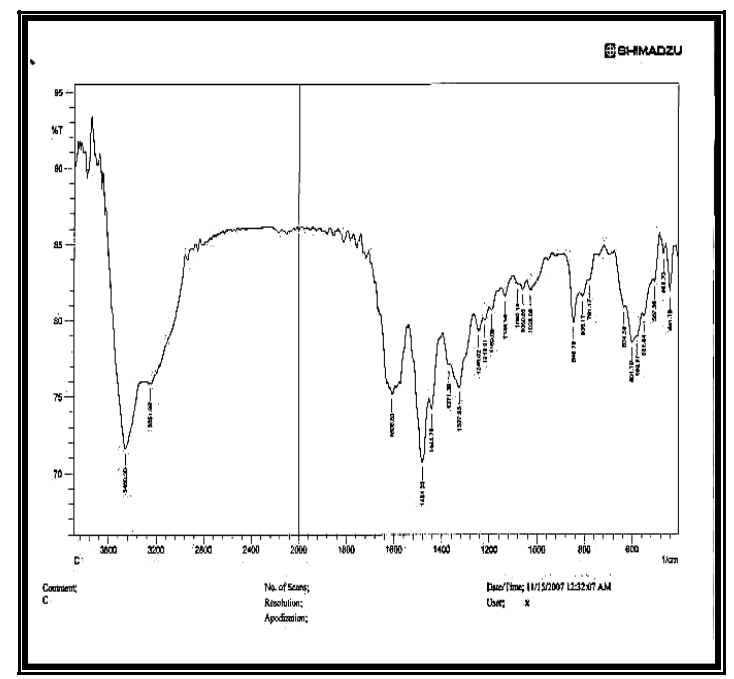

Figure (6): FTIR spectrum for $\mathrm{Cis}-\left[\mathrm{Pt}(4-\mathrm{ASA})\left(\mathrm{NH}_{3}\right)_{2}\right] \mathrm{I}$

\section{XRD spectra:}

$\mathrm{X}$-ray diffraction angles(degree) for the complex cis-[Pt(NH$\left.\left.)_{2} \mathrm{I}_{2}\right)\right]$ are 12.68 , 18.06 and 39.19, the first value belongs to $\mathrm{Pt}(11)$, that ensures that the complex contains $\mathrm{Pt}(1 \mathrm{ll})$ rather than $\mathrm{Pt}(\mathrm{lV})$ ion, which ensures what we want. Table (3) and figure (7) show these results. 
Table (3): XRD data for the cis - iodoplatin complex

\begin{tabular}{|c|c|c|}
\hline Compounds & $\begin{array}{ll}2 & \text { Theta } \\
\text { (deg.) } & \end{array}$ & $\mathbf{I} / \mathbf{I}_{2}$ \\
\hline$\left.\left(\mathrm{Cis}-\left[\mathrm{Pt}\left(\mathrm{NH}_{3}\right)_{2} \mathrm{I}_{2}\right)\right]\right)$ & $\begin{array}{l}12.68 \\
18.06 \\
39.19\end{array}$ & $\begin{array}{l}100 \\
15 \\
14\end{array}$ \\
\hline
\end{tabular}

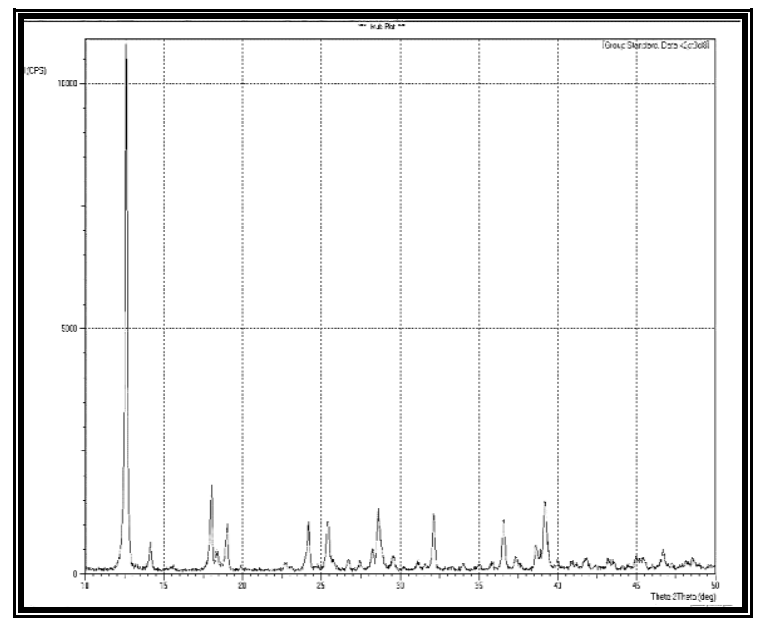

Figure (7): XRD spectrum for cis-[Pt(NH3)2 $\left.\left.\mathbf{I}_{2}\right)\right]$ complex

\section{${ }^{1}$ HNMR Spectra}

${ }^{1} \mathrm{HNMR}$ spectra of the complexes cis-[Pt( $\left.\left.\left(\mathrm{NH}_{3}\right)_{2} \mathrm{I}_{2}\right)\right]$, cis-[Pt(4-AAP) $\left.\left(\mathrm{NH}_{3}\right)_{2}\right]$ $\left.\mathrm{I}_{2}\right)$ and cis-[Pt(4-ASA) $\left.\left(\mathrm{NH}_{3}\right)_{2}\right] \mathrm{I}$ had been studied. ${ }^{1} \mathrm{HNMR}$ spectrum of the complex cis-[ $\left.\left.\mathrm{Pt}\left(\mathrm{NH}_{3}\right)_{2} \mathrm{I}_{2}\right)\right]$ shows an appearance a single peak at $3.32 \mathrm{ppm}$ which belongs to the six protons of the two groups of $\mathrm{NH}_{3}$ as obvious in figure $8 .{ }^{1} \mathrm{HNMR}$ spectrum of the complex cis-[Pt(4-AAP) $\left.\left(\mathrm{NH}_{3}\right)_{2}\right] \mathrm{I}_{2}$ shows an appearance of a single peak at 6.70 ppm which belongs to the benzene ring within the complex and two single peaks at $2.09 \mathrm{ppm}$ and $2.70 \mathrm{ppm}$, the first belongs to $\mathrm{CH}_{3}$ group that attached to carbon atom and the second belongs to $\mathrm{CH}_{3}$ group that attached to nitrogen atom in pyrol ring, additionally, there is a single peak at 3.8 ppm belongs to $\mathrm{NH}_{2}$ group, figure 9 shows all these peaks. ${ }^{1} \mathrm{HNMR}$ spectrum of the complex cis-[Pt(4-ASA) $\left.\left(\mathrm{NH}_{3}\right)_{2}\right] \mathrm{I}$ shows an appearance of a single peak at $7.10 \mathrm{ppm}$ which belongs to the aromatic ring, also there is a single peak at $3.33 \mathrm{ppm}$ which belongs to $\mathrm{NH}_{2}$ group, additionally, there 
are two peaks at $2.74 \mathrm{ppm}$ and $2.09 \mathrm{ppm}$ which belong to $\mathrm{NH}_{3}$ group. All these peaks proved that the ligands and the ion metal joined together to form the complexes.

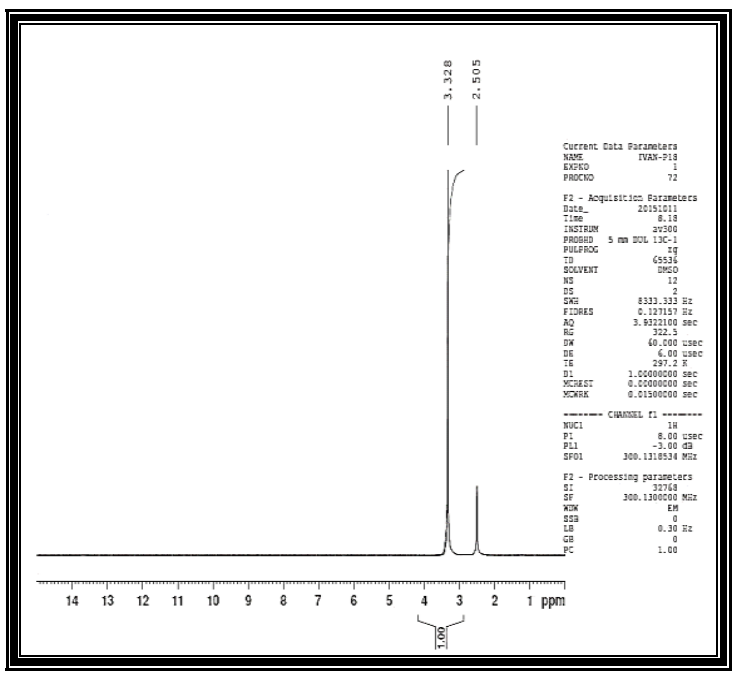

Figure (8): ${ }^{1} \mathrm{HNMR}$ spectra for cis- $\left.\left[\mathrm{Pt}\left(\mathrm{NH}_{3}\right)_{2} \mathrm{I}_{2}\right)\right]$ complex

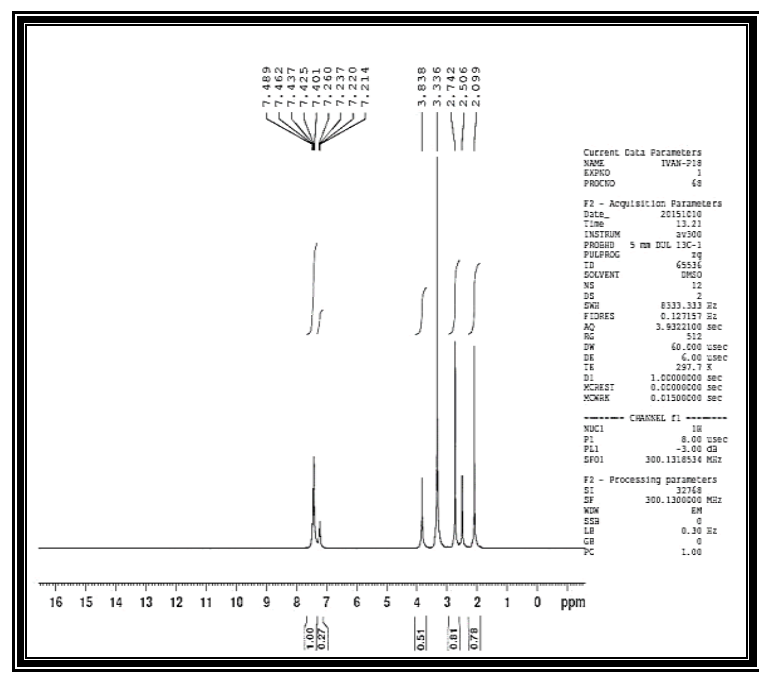

Figure (9): ${ }^{1} \mathrm{HNMR}$ spectra for cis-[Pt(4-AAP) $\left.\left(\mathrm{NH}_{3}\right)_{2}\right] \mathrm{I}_{2}$ complex 


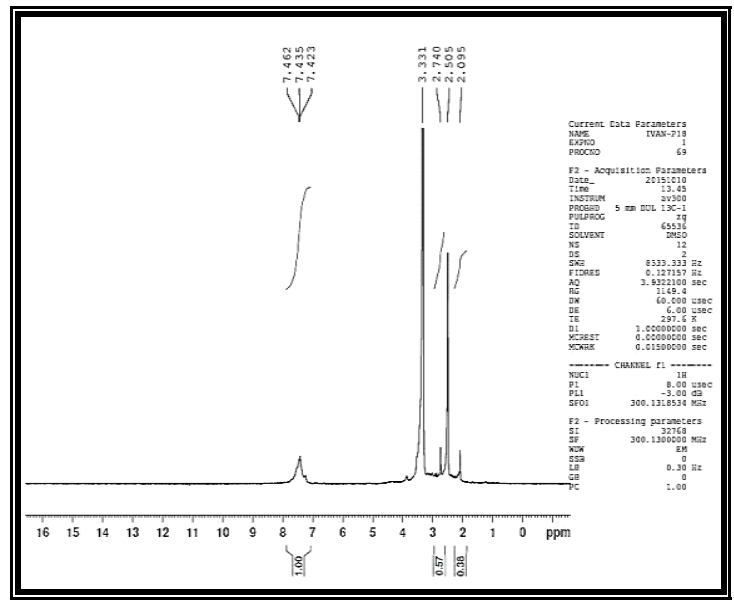

Figure (10): ${ }^{1} \mathrm{HNMR}$ spectrum for cis-[Pt(4-ASA) $\left.\left(\mathrm{NH}_{3}\right)_{2}\right] \mathrm{I}$ complex

The effect of concentration on molar conductivity:

The effect of concentration on the molar conductivity was studded for the solutions of the complexes. This study shows that the complexes cis-[Pt(4-AAP) $\left.\left(\mathrm{NH}_{3}\right)_{2}\right] \mathrm{I}_{2}$ and cis-[Pt(4-ASA) $\left.\left(\mathrm{NH}_{3}\right)_{2}\right] \mathrm{I}$ have an increase in the molar conductivity with the increasing in the concentration of the complexes. Table (4) and figures $(11,12)$ show the data of this study.

Table (4): the effect of conc. on molar conductivity for the complexes.

\begin{tabular}{|c|c|c|}
\hline Con. (M) & $\begin{array}{c}\text { Cond. } \mathbf{M c} / \mathbf{c m} \\
\text { Cis-[Pt(4-AAP)(NH3) } \mathbf{2}_{2} \mathbf{I}_{2}\end{array}$ & $\begin{array}{c}\text { Cond. Mc/cm } \\
\text { Cis-[Pt(4-ASA) } \\
\text { (NH3) } \mathbf{2}] \mathbf{I}\end{array}$ \\
\hline 0.0001 & 2.24 & 38.8 \\
\hline 0.0005 & 4.76 & 156.0 \\
\hline 0.0010 & 8.45 & 278.0 \\
\hline 0.0020 & 13.79 & 502.0 \\
\hline 0.0030 & 18.82 & 722.0 \\
\hline 0.0040 & 23.20 & 1105.0 \\
\hline 0.0050 & 27.60 & 1243.0 \\
\hline 0.0060 & 32.00 & 1481.0 \\
\hline 0.0070 & 36.30 & 1591.0 \\
\hline 0.0080 & 39.50 & \\
\hline
\end{tabular}




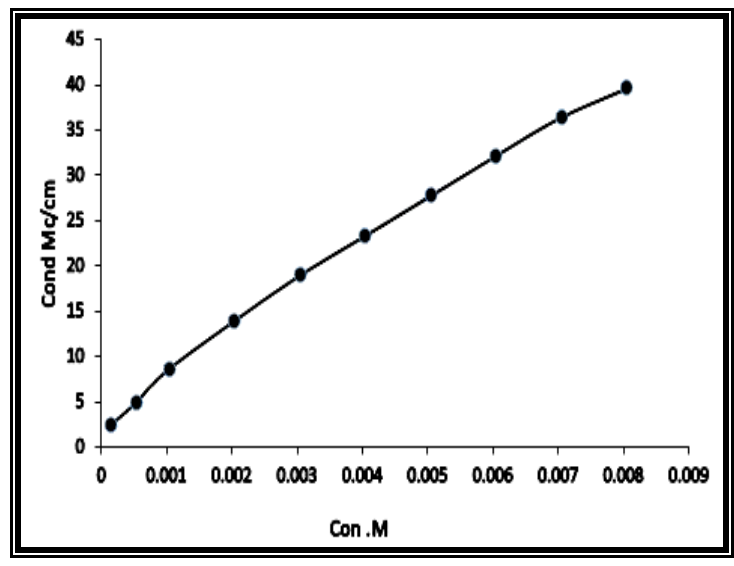

Figure (11): The effect of con. on the cond. for the complex cis-[Pt(4-AAP) (NH3) $)_{2} \mathbf{I}_{2}$

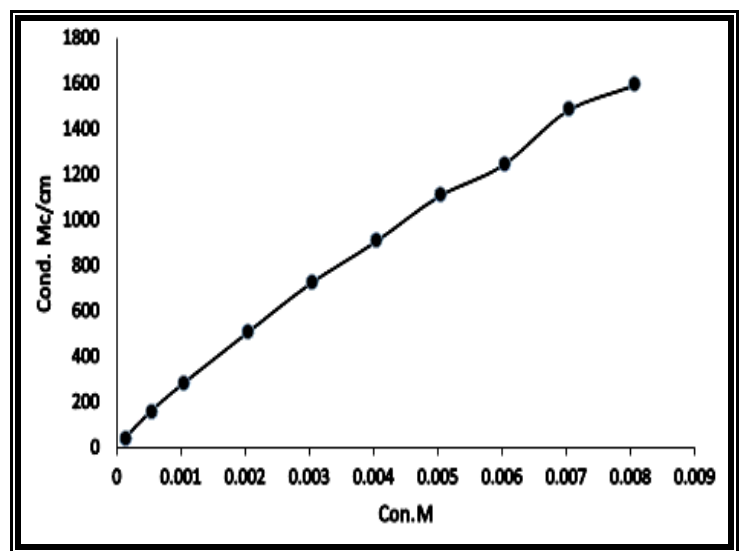

Figure (11): The effect of con. on the cond. for the complex cis-[Pt(4-ASA) (NH3) ${ }_{2} \mathbf{I}_{2}$

\section{The effect of temperature on molar conductivity:}

The effect of temperature on the molar conductivity of the complexes $\left(1 \times 10^{-3} \mathrm{M}\right)$ has been studied. The complexes cis-[Pt(4-AAP) $\left.\left(\mathrm{NH}_{3}\right)_{2}\right] \mathrm{I}_{2}$ and cis-[Pt(4-ASA) $\left(\mathrm{NH}_{3}\right)_{2}$ ]I had shown that there is an increase in the molar conductivity with an increase the temperature. Table (5)and figures $(13,14)$ show the results of this study. 
Table (5): The effect of temp. on the molar conductivity of the complexes.

\begin{tabular}{|c|c|c|}
\hline $\begin{array}{c}\text { Temp. } \\
\text { C }^{0}\end{array}$ & $\begin{array}{c}\text { Cond. } \mathrm{Mc} / \mathrm{cm} \\
\text { Cis-[Pt(4- } \\
\left.\text { AAP })\left(\mathrm{NH}_{3}\right)_{2}\right] \mathrm{I}_{2}\end{array}$ & $\begin{array}{c}\text { Cond. } \mathrm{Mc} / \mathrm{cm} \\
\text { Cis-[Pt(4-ASA) } \\
\left.\left(\mathrm{NH}_{3}\right)_{2}\right] \mathrm{I}\end{array}$ \\
\hline 20 & 1.76 & 97.0 \\
\hline 25 & 2.00 & 98.4 \\
\hline 30 & 2.19 & 99.3 \\
\hline 35 & 2.50 & 99.9 \\
\hline 40 & 3.00 & 101.1 \\
\hline 45 & 3.34 & 101.2 \\
\hline 50 & 3.36 & 101.6 \\
\hline 55 & 3.40 & 102.0 \\
\hline 60 & 3.80 & 102.2 \\
\hline 65 & 4.32 & 102.3 \\
\hline 70 & 4.68 & 102.3 \\
\hline 75 & 5.13 & 102.4 \\
\hline 80 & 5.65 & 102.4 \\
\hline
\end{tabular}

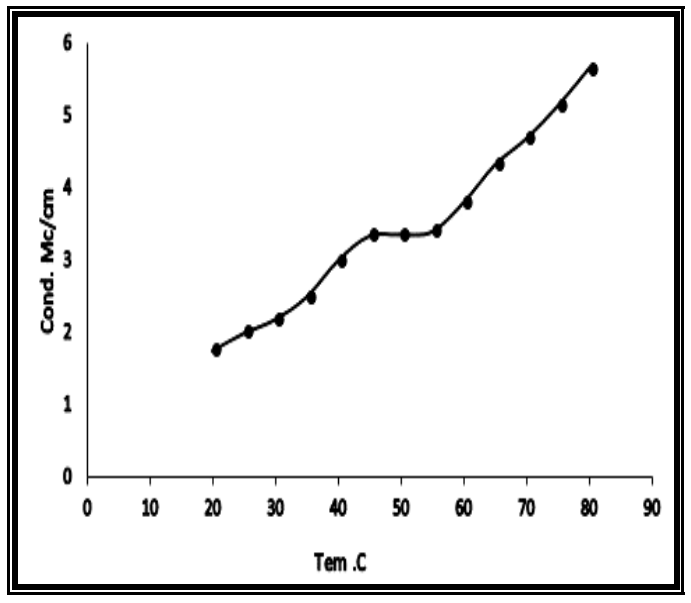

Figure (13): Effect of temp. on cond. cis-[Pt(4-AAP) (NH3)2] $\mathbf{I}_{2}$ 


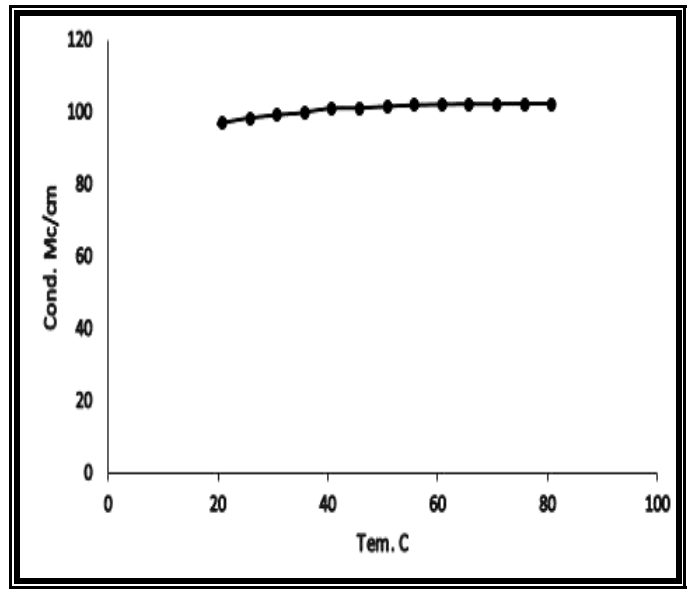

Figure (14): Effect of temp. on cond. cis $\left[\mathrm{Pt}(4-\mathrm{ASA})\left(\mathrm{NH}_{3}\right)_{2}\right] \mathrm{I}$

The effect of temperature on the stability of the complexes:

The effect of temperature on the stability of the complexes had been studied by using UV.Vis. spectroscopy in which the absorbance of the solutions were measured. This study shows that the complex cis-[Pt(4 ASA) $\left.\left(\mathrm{NH}_{3}\right)_{2}\right] \mathrm{I}$ is stable until $50{ }^{0} \mathrm{C}$ and above this degree begins to break part, while the complex cis$\left[\mathrm{Pt}(4 \mathrm{AAP})\left(\mathrm{NH}_{3}\right)_{2}\right] \mathrm{I}_{2}$ stable until $80{ }^{\circ} \mathrm{C}$, that may be because of the composition structure of the ligands. Table (6) and figures $(15,16)$ show this study.

Table (6): the effect of temperature on the complexes stability

\begin{tabular}{|c|c|c|}
\hline $\begin{array}{c}\text { Tem. }^{0} \\
\mathbf{C}\end{array}$ & $\begin{array}{c}\text { Abs. } \\
\text { Cis- }\end{array}$ & $\begin{array}{c}\text { Abs. } \\
\text { Cis-[Pt(4 ASA) } \\
\left.\mathbf{( N H}_{3} \mathbf{2}_{2}\right] \mathbf{I}\end{array}$ \\
\hline 20 & 1.6121 & 0.1320 \\
\hline 25 & 1.6443 & 0.0999 \\
\hline 30 & 1.6578 & 0.0961 \\
\hline 35 & 1.6649 & 0.0960 \\
\hline 40 & 1.6767 & 0.0538 \\
\hline 45 & 1.6852 & 0.0445 \\
\hline
\end{tabular}




\begin{tabular}{|c|c|c|}
\hline 50 & 1.6960 & 0.0405 \\
\hline 55 & 1.7130 & 0.0237 \\
\hline 60 & 1.7812 & 0.0166 \\
\hline 65 & 1.8144 & 0.0136 \\
\hline 70 & 1.9256 & 0.0030 \\
\hline 75 & 1.9783 & 0.0010 \\
\hline 80 & 1.9970 & 0.0005 \\
\hline
\end{tabular}

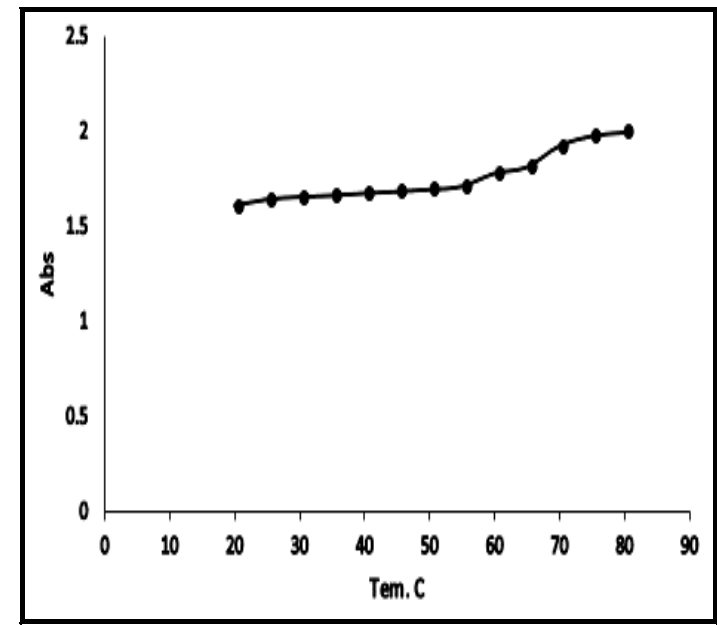

Figure (15): The effect of temp. on the stability of cis-[Pt(4AAP) (NH3) $)_{2} I_{2}$ complex

\section{Determination of the expiry date of the complexes:}

The expiry date of the complexes were determined in $35^{\circ} \mathrm{C}$ and $20^{\circ} \mathrm{C}$ for the solutions of the complexes $\left(1 \times 10^{-3} \mathrm{M}\right)$. This study shows that the expiry date at $35^{\circ} \mathrm{C}$ of the complex cis-[Pt(4AAP) $\left.\left(\mathrm{NH}_{3}\right)_{2}\right] \mathrm{I}_{2}$ is 270 hours, while it is for the complex cis- $\left[\mathrm{Pt}\left(4\right.\right.$ ASA) $\left.\left(\mathrm{NH}_{3}\right)_{2}\right] \mathrm{I}$ is 420 hours and at $20^{\circ} \mathrm{C}$ the expiry date is between 410 435 hours for both complexes. Table $(7,8,9)$ and figures $(17,18,19,20)$ show this study. 
Table (7): Expiry date data at $35^{\circ} \mathrm{C}$ of the complexes

\begin{tabular}{|c|c|c|}
\hline $\begin{array}{c}\text { Tim. } \\
\text { hour }\end{array}$ & $\begin{array}{c}\text { Abs. } \\
\text { Cis-[Pt(4AAP) } \\
\left(\mathbf{N H}_{3} \mathbf{2}_{2} \mathbf{I}_{\mathbf{2}}\right.\end{array}$ & $\begin{array}{c}\text { Abs. } \\
\text { Cis-[Pt(4 ASA) } \\
\left.(\mathbf{N H})_{2}\right] \mathbf{I}\end{array}$ \\
\hline 0 & 2.5970 & 2.6032 \\
\hline 48 & 2.5600 & 2.2898 \\
\hline 96 & 2.1970 & 2.0759 \\
\hline 144 & 2.1430 & 2.0495 \\
\hline 192 & 1.9660 & 2.0162 \\
\hline 240 & 1.8760 & 1.8987 \\
\hline 288 & 1.8320 & 1.6981 \\
\hline 336 & 1.5390 & 1.5723 \\
\hline 384 & 1.2530 & 1.3259 \\
\hline 432 & 1.0100 & 1.1216 \\
\hline
\end{tabular}

Table (8): Expiry date data at $20^{\circ} \mathrm{C}$ of the complexes

\begin{tabular}{|c|c|c|}
\hline $\begin{array}{l}\text { Tim. } \\
\text { hour }\end{array}$ & $\begin{array}{c}\text { Abs. } \\
\text { Cis-[Pt(4AAP) } \\
\left.\left(\mathrm{NH}_{3}\right)_{2}\right] \mathrm{I}_{2}\end{array}$ & $\begin{array}{c}\text { Abs. } \\
\left.\text { Cis-[Pt(4 } \quad \text { ASA })\left(\mathrm{NH}_{3}\right)_{2}\right] I\end{array}$ \\
\hline 0 & 2.4700 & 3.1169 \\
\hline 48 & 2.2350 & 2.5199 \\
\hline 96 & 2.1600 & 2.3489 \\
\hline 144 & 1.9020 & 2.1471 \\
\hline 192 & 1.8990 & 2.0467 \\
\hline 240 & 1.8110 & 2.0348 \\
\hline 288 & 1.7380 & 2.0322 \\
\hline 336 & 1.4000 & 2.0283 \\
\hline 384 & 1.2200 & 1.8633 \\
\hline 432 & 0.9620 & 1.2434 \\
\hline
\end{tabular}




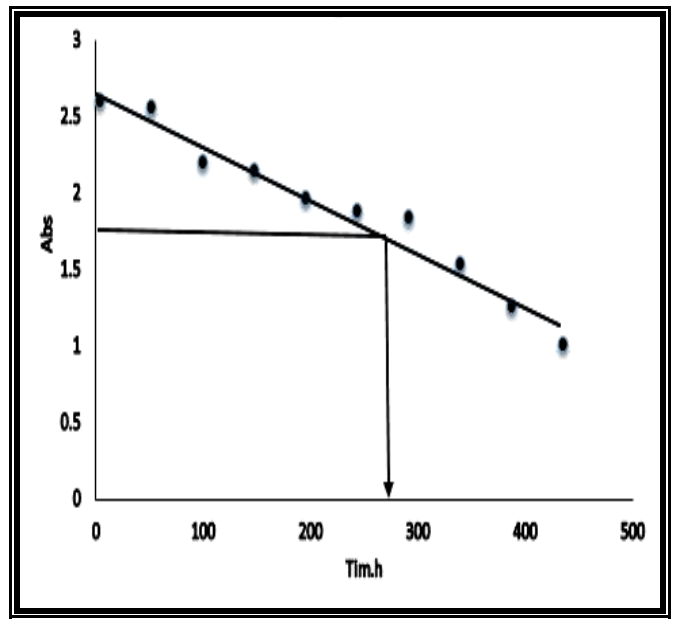

Figure (17): Expiry date for cis-[Pt(4-AAP) $\left.\left(\mathrm{NH}_{3}\right)_{2}\right] \mathrm{I}_{2}$ at $35^{\circ} \mathrm{C}$

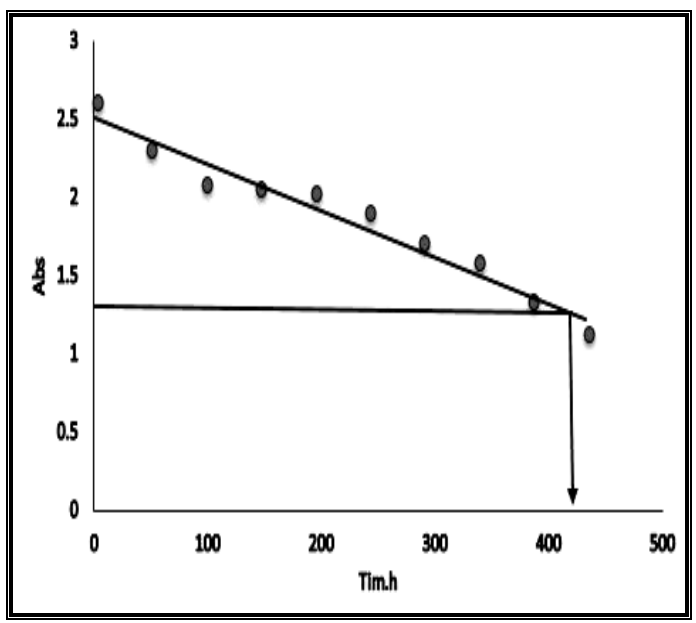

Figure (18): ): Expiry date for cis-[Pt(4-ASA) $\left.\left(\mathrm{NH}_{3}\right)_{2}\right] \mathrm{I}$ at $35{ }^{\circ} \mathrm{C}$ 


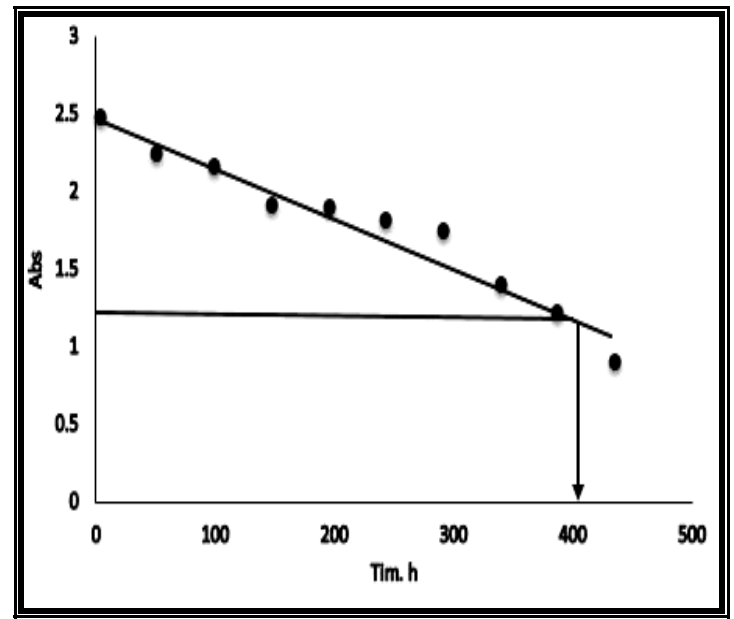

Figure (19): Expiry date for cis-[Pt(4-AAP) $\left.\left(\mathrm{NH}_{3}\right)_{2}\right] \mathrm{I}_{2}$ at $20{ }^{\circ} \mathrm{C}$

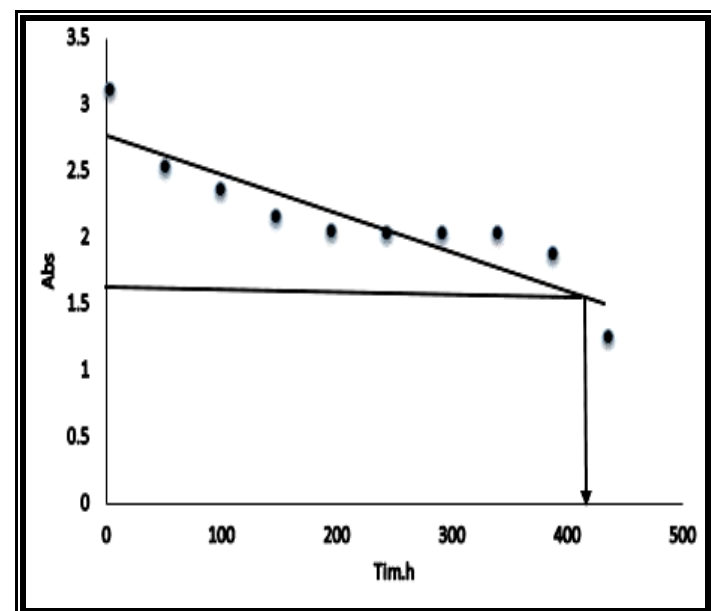

Figure (20): Expiry date for cis-[Pt(4-ASA) $\left.\left(\mathrm{NH}_{3}\right)_{2}\right] \mathrm{I}$ at $20^{\circ} \mathrm{C}$

Table (9): Expiry date of the complexes in hours

\begin{tabular}{|l|l|l|}
\hline Complexes & $\left(\mathbf{t}_{1 / 2}\right)$ in $\mathbf{3 5 - 4 0}{ }^{\circ} \mathbf{C}$ & $\left(\mathbf{t}_{\mathbf{1} / 2}\right)$ in $\mathbf{2 0}^{\circ} \mathbf{C}$ \\
\hline Cis-[Pt(4-AAP) $\left.\left(\mathrm{NH}_{3}\right)_{2}\right] \mathrm{I}_{2}$ & $270 \mathrm{~h}$ & $410 \mathrm{~h}$ \\
\hline Cis-[Pt(4-ASA) $\left.\left(\mathrm{NH}_{3}\right)_{2}\right] \mathrm{I}$ & $420 \mathrm{~h}$ & $435 \mathrm{~h}$ \\
\hline
\end{tabular}




\section{CONFLICT OF INTERESTS.}

There are non-conflicts of interest.

\section{References}

[1] Molina Dula Options Cal Medi Connect Plan Medicare - Medicade Plan H8677 - 14 - 15103 - 0004 - MMPCARX Ar Approved HPMS Approved Formulary File Submission 00014303, Version 12, 2014.

[2] Jamison E. R. and Lippard S., Structure, Recognition and Processing of Cis Platin DNA Adducts, J. Chem. Rev., vol 99,2467 - 2498, 1999.

[3] Turek J. J., Leamon C. P. and Low P. S., Endocytosis of Flate - Protein Conjugates, Vltra - Structural Localization in KB Cells, J. Cell Sci., vol 106, 423 - 430, 1993.

[4] Bueno R, Appasani K, Mercer H, Laster S, Sugrbaker D, J. Thorac. Cardiovasc. Sury. , vol 121, 225-233, 2001.

[5] Yuichi A, Tomoyo S, Yoshinari Y, Yoshinari H, J. Medi. Sci., vol76, 1-9, 2014.

[6] Robert R. C., Frederic L., Loanna S. M. P. and Roberta J. W., Biological Inorganic Chemistry An Introduction, Oxford OX5 IGB, UK, $1^{\text {st }}$ Edition, 2008.

[7] Kauffman GB, Cowan DO, Inorg. Synth. , vol 5, 239-245, 1963.

[8] Dhara SC, Indian J. Chem.vol 8, 1338-1346, 1970.

[9] Rhoda RN, Suffern NY, Crosby JN, U. S. Patent, 4, 273, 755, Jun. 16, 1981.

[10] Rebecca AA, Matthew DH, Trevor WH, J. of Chem., vol 83, 728-734, 2006.

[11] Al- Mukhtar, Mustafa IA, Arabic Version, Mosul University Press, 469, 64,618,647,669, 1988.

[12] Jian-ning L, Bo-Wan W, Bing Z, Yongchum L, Turk J. Chem., vol 30, 41-48, 2006.

[13] Hashem EY, J. AOAC Intr., 84, 2, 537-545, 2001.

[14] Al-Hamadan UJ, Gassim TH, Radhy TE, Molecules, vol 15, 5620-5628, 2010.

[15] Rajasekar K., Ramachandramoorthy T. and Paulraj A., Microwave Assisted Synthesis, Structural Characterization and Biological Activities of 4 - Amino anti pyridine and Thiocynate Mixed Ligand Complexes, Res. J. Pharmaceutical Sci.,vol 1, no.14, 22 - 27, 2012.

\section{الخلاصة}

يتضمن هذا البحث تحضير معقد جديد للسز - بلاتين بصيغة الآيودين ( Cis - lodoplatin ) وكللك معقدين جديدين

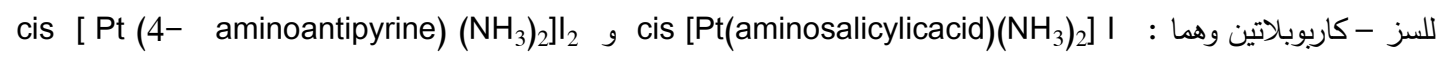
4-amino salicylic acid : واللذان يمكن ان يستخدما كعقاقير ضد السرطان، وقد حضرا باستخدام الليكاندات العضوية alamino antipyrine, درست تأثير التركيز ودرجة الحرارة على التوصيلية الكهربائية لمحاليل هذه المعقدات. وقد حدد تاريخ انتهاء الصلاحية (عر النصف) لمحاليل هذه المعقدات في ظروف درجة الحرارة 35 و 20 درجة مئوية. 